Please do not remove this page

RMIT

UNIVERSITY

Passionate amateurs: The Experimental film and television fund and modernist film practice in Australia

French, Lisa; Poole, Mark

https://researchrepository.rmit.edu.au/esploro/outputs/9921858119601341/filesAndLinks?institution=61RMIT_INST\&index=null

French, L., \& Poole, M. (2011). Passionate amateurs: The Experimental film and television fund and modernist film practice in Australia. Studies in Australasian Cinema, 5(2), 171-184.

https://doi.org/10.1386/sac.5.2.171_1

Published Version: https://doi.org/10.1386/sac.5.2.171_1

Repository homepage: https://researchrepository.rmit.edu.au

(C) 2011 Intellect Ltd Article

Downloaded On 2023/04/26 19:04:38 +1000

Please do not remove this page 
French, L and Poole, M 2011, 'Passionate amateurs: The experimental film and television fund and modernist film practice in Australia', Studies in Australasian Cinema, vol. 5, no. 2, pp. 171-184.

\title{
Passionate amateurs: The experimental film and television fund and modernist film practice in Australia
}

Lisa French and Mark Poole, RMIT University

\begin{abstract}
Most histories of the dynamism of the Australian film industry in the 1970s explore feature films, but a vital part of the creativity and energy of the revival occurred in the non-feature sector. A significant site of experimentation and originality in form, content and technique was the Experimental Film and Television Fund (EFTF). From its inception in 1970, The Australian Film Institute (AFI) managed the fund until 1977 when the Australian Film Commission (AFC) assumed control of it. Drawing on a series of interviews with key players involved in the fund during the AFI's tenure, and research for the book, Shining a Light: 50 Years of the Australian Film Institute (French and Poole 2009), this article traces this significant period of the history of Australian film production, and proposes that the AFI played an important role in promoting modernist film practice, and the Australian film revival, through its management of the EFTF.
\end{abstract}

\section{Keywords}

AFI

screen culture

government subsidy

EFTF

revival 
renaissance

experimental film

[The Experimental Film and Television Fund is] one of the best things we have. It embodies our communal recognition that film is something other and more than Love Story, that it's a pervasive, polymorphous, infinitely variegated form of late $20^{\text {th }}$ century expression which can and should be within the grasp of many.

(Lawson 1972: 18)

The establishment of the Experimental Film and Television Fund (EFTF) in 1970 was a plan to hatch latent creativity. It was assumed that dormant talent lay waiting and funding would bring it to life. Indeed, for decades prior to revival of the industry in the 1970s, Australians were making non-feature documentary and avant-garde films (see Gerbaz 2008), despite a dearth in feature production. Australian culture was in vogue and finally getting support; the Australia Council for the Arts (now Australia Council) was recently founded (1968), and in 1969 it announced plans to boost the industry, including an experimental fund (see Reade 1981: 161). In 1970, the EFTF was established under the auspice of the Australian Film Institute (AFI). While the Gorton government's aspirations were to support training, those managing the EFTF at the AFI had an eye to art, and as this article argues, the fund (through the AFI) produced a significant body of Australian modernist film work, and made a major contribution to the revival of the Australian film industry in the 1970s. 
Phillip Adams (who later became a chair of the AFI, 1971-1973) has recalled that he wrote a note to the newly appointed John Gorton declaring, 'It's time to see our own landscapes, hear our own voices and dream our own dreams' (2008). He was not alone, and as Dermody and Jacka have observed, one of the main catalysts for the revival of the industry in the 1970s was the intense lobbying of government from the film buff or art film movement (1987: 52). In Melbourne, those at the AFI were involved in the lobby, while in Sydney, Albie Thoms and Ubu Films ${ }^{1}$ were a 'casual factor in the political developments' that led to the EFTF (Zuvela 2003), and critics such as Sylvia Lawson were bemoaning the lack of an industry ([1965] 1985). The significant body and range of film practice funded by the EFTF enabled these landscapes, voices and dreams, greatly enriching Australian screen and modernist culture. According to Lawson, the EFTF was established for highly political reasons, but it enabled 'visual art to come into being' (1972: 18).

Barry Jones, who was a governor of the AFI, and later its chairperson (1974-1980), has recalled that he and Phillip Adams engaged in a certain political opportunism by achieving 'quite enthusiastic bi-partisan support to do something about developing or reviving or even exhuming an Australian feature film industry’ (2008). Following the disappearance of Prime Minister Harold Holt while swimming off Portsea, Gorton had come into office as prime minister unexpectedly, and was looking for something where he could make his mark. No other prime minister had previously taken a personal interest in promoting a film agenda, and history was made. Had Gorton not had an affinity with film, and Adams and Jones not been advising him, the Australian film industry may well have not had a renaissance in the 1970s. However, the pieces fell into place. 
The fund was established as the first step in a broader plan by the Gorton government to revive the industry through directly funding production: and from this perspective, the EFTF is historically important. Other initiatives were the establishment of the Australian Film Development Corporation (AFDC) in 1970, on which Barry Jones was an inaugural board member. The AFDC funded commercial feature films, most notably the 'ocker' comedies of the early 1970s, which created a popular interest in Australian film at the time (e.g. Stork in 1971, The Adventures of Barry McKenzie in 1972 and Alvin Purple in 1973). The AFDC was replaced in 1975 by the Australian Film Commission (AFC), whose funding policy shifted to more culturally respectable period films, such as Peter Weir's 1975 film Picnic at Hanging Rock, instigating a trend later referred to as the 'AFC' genre (Dermody and Jacka 1988: 32-33). In addition, a film school was part of the plan: The Australian Film and Television School (the antecedent to AFTRS, which was established in 1973) made an important impact in non-feature film-making from the mid1970s, and in building technical skills of the Australian film and television industry. These initiatives and others, such as state film funding agencies from 1972 (the South Australian Film Corporation being the first) were part of a general flowering of film culture at the time, all of which contributed to a more productive and energized screen sector and increased interest and activity in both production and cultural activities that were deemed to be Australian - although the Commonwealth Film Unit, which became Film Australia in 1973, and joined Screen Australia in 2008, had been performing this role under different names since 1945 (particularly in documentary). 
According to film historian Ken Berryman, who has written a comprehensive history of the Fund that covers the period when the AFI administered it, the management of the EFTF gave the institute 'new significance in the 1970s' (1985: 19). Through the AFI, the EFTF handed out almost two million dollars to Australian film-makers for 828 projects (Berryman 1985: 75). It was the first form of federal support the AFI had ever received in its then twelve-year history, as prior to that it had largely run the Melbourne Film Festival and some other unfunded screen culture activities (French and Poole 2009: 42).

\section{Screen culture}

As we have written elsewhere (French and Poole 2009: 4), screen culture encompasses all the activities within a screen community, including the production industry, distribution, exhibition, critical commentary, education, promotion, lobbying and other discourses and contexts for the reception of screen products. As a cultural enterprise, the EFTF shaped screen culture not just during its existence, but also in a way that has continued to be felt today. The evidence for this is flagged in Berryman's thesis, which includes the observations of Murray Brown (a former EFTF administrator), who noted that when the Gorton government funded the triad of the EFTF, the film school, and the AFDC (which they did by approving the implementation of the Interim Report of the Film and Television Committee, 1969), they were establishing a ‘separation of film industry and film culture' (1985: 186). The significance of this point about the separation of film industry and film culture is that this division continued to impact on the way in which screen culture was funded and defined from 1970 until the present day. 'Production' and 'screen culture’ sectors have been artificially divided for funding purposes, and this separation can be traced back to the structural support for the industry provided by the 
Gorton government from 1970.

It is most likely that the consequences of the funding decision were not intended. But by creating separate funding programmes, the separation was entrenched. 'Film culture' (now screen culture) on the one hand was funded in three ways: (1) outside of specific programmes with the Film and Television Board providing assistance directly to cultural organizations (ABS 1974: 1022); (2) through the EFTF, which, having the AFI (a screen culture organization) as its auspice, funded production but with a solid focus on culture or art; and (3) the Film School. The production sector was funded separately. From 1970 this was via the AFDC, who funded feature films and television rather than experimental, short, documentary or animated films.

\section{Setting up the EFTF}

$[\ldots]$ the whole underground film movement $[\ldots]$ was gaining vogue $[\ldots]$ All of these elements coalesced in Australia with the introduction of the Experimental Film Fund $[\ldots]$.

Philip Noyce (quoted in Petzke 2004: 23)

The finance for the EFTF was provided through the Australian Council for the Arts, whose Film Board, chaired by Phillip Adams, initiated the programme. ${ }^{2}$ Colin Bennett, then a governor of the AFI, drafted guidelines for the fund, which he later observed became a 'germinating' force, injecting new life and preventing stagnation (2008). So the AFI was in a position of influence or privilege at this time. Given the impact of the EFTF, and that the Melbourne Film Festival and the AFI were at that time the same 
organization, the AFI was arguably a central player in the renaissance of the industry and playing an invaluable role in nurturing film as art. As David Stratton has observed, in Melbourne the lobby for the revival 'centred around Phillip Adams, Barry Jones and Erwin Rado and the Melbourne Film Festival-Australian Film Institute people' (1980: $10)^{3}$

The initiation of the fund began a shift for film-makers from the usual route at that time, which was working for a broadcaster or the Commonwealth Film Unit. The EFTF established a new direction that is still in place today: a subsidized film and television industry. It had the effect of moving the industry away from documentary (which dominated production at the time), and towards drama (50 per cent of the work funded).

\section{A modernist flowering and slingshots from the camp of the Philistines}

The rag-bag of flashing lights, blobs and snorts, and wandering plink-plonks ... (Ellis 1972)

Modernist film practice is notable for 'experiments with form, and work that draws attention to the processes and materials used (and to the further tendency of abstraction)' (Gardner et al. 1991: 953), and 24 per cent of the works funded by the EFTF were experimental (Berryman 1985: 69). ${ }^{4}$ Although some of those in the 'experimental category' were clearly experimenting, other funding recipients used the funds to hone their craft as film artisans. According to John Flaus, film-maker Paul Winkler always maintained that his films, five of which were funded by the EFTF during the AFI's tenure, 'were not experimental, he always knew exactly what he was doing' (2010). ${ }^{5}$ This 
is no doubt also true of many of the other film-makers who were working in avant-garde, and who were funded through the EFTF - amongst them Arthur and Corrine Cantrill (funded in 1971 for Skin of Your Eye), Dirk de Bruyn (funded in 1976 for Feyers), Sarah Gibson and Susan Lambert (funded in 1975 for Ailsa: A Woman Sculptor) and Albie Thoms (funded in 1970 and 1972 for Sunshine City).

The guidelines for the fund were consistent with modernist practice in focusing on form over content and style of subject matter, directing that 'experimental' should be understood in broad terms to include films that were 'original in approach, technique or subject matter', or alternatively 'technical research projects', or 'experiments by inexperienced but promising film-makers' (EFTF guidelines, 1970).

The emphasis on film as art caused some criticism of the EFTF; Lawson observed that attacks on the fund were largely of two kinds, that the:

film trade and TV execs hate the fund because, they say, it encourages sloppy individualism - 'these longhairs don't understand that people go to the pictures to be entertained'. [...] Some of the film and distribution men like to point to the more incoherent examples of avant-garde filmmaking and use them as sticks with which to beat local film industry campaigners. These of course are slingshots from the camp of the Philistines... (1972: 18)

The struggle between the differing and usually opposing demands of culture and industry ('art or culture' versus ‘industry or commerce') has been a continuous tension for the industry, and for the AFI. This tension was present for the EFTF who had a government 
seeking a training ground, and an auspice in the AFI who sought to promote film as art, and support an industry to produce it.

Even those working in the avant-garde were not entirely convinced of the project of the EFTF. Albie Thoms (who was funded himself) described it as 'an experiment' in the sense that it was an 'attempt to succeed with a local industry that has failed dismally in all previous attempts’ (Berryman 1985: 3). In attempting to address Thoms’ comments, and contextualize the various engagements with the use of the term 'experimental', Bennett said it was meant to denote originality in approach, technique or subject matter, and to allow promising film-makers the opportunity to experiment (Berryman 1985: 4).

\section{Seeding the industry}

The criterion then was that talent should be supported if it showed that it had imagination, quality, guts, whatever - whether you could sell it or not. (John Flaus quoted in Berryman 1985: 184)

The AFI's leadership in establishing momentum for the EFTF (both in lobbying for it and managing it) began with the selection of a range of industry persons - several of whom are now very successful directors - to undertake various roles for the fund. The first production adviser to the EFTF was Bruce Beresford, who was romantically described in the press as 'tousle-haired' and wearing 'mod suits reminiscent of pre-war Chicago' (Gill 1971). This romanticizing was part of a general press tendency to idealize what was going on in the industry at the time. Bennett recalled that Beresford managed the fund for something like a couple of years (2008), having been the first production officer of a 
similar fund: the BFI Production Board. One of his tasks was to seek distribution outlets. There were six assessors at any one time providing reports and those chosen for this job included people such as Fred Schepisi, Colin Bennett and Mal Bryning (Berryman 1985: 20).

AFI director Erwin Rado stated that the first round of films made via the EFTF were of two types: people experimenting without any experience, and those who were 'established filmmakers who are already in the industry making documentaries, commercials and so on but who want to try their hand at making a fiction film' (n.a. 1970). This building of above the line, non-technical skills was all part of the plan to develop the industry and, importantly, indicates that people were working in some kind of industry at the time - albeit a non-feature one. Some key films of the 1970s had their genesis through the fund; for example, Tim Burstall had a grant from the fund to make a documentary on the La Mama Theatre, but watching a play in which Alan Finney acted, and was co-director, he decided instead on the project that became the 1971 film Stork (Finney 2007).

Ken Berryman, who read all the correspondence between the film-makers and the fund administrators claims that those administrators turned themselves inside out to try and help the film-makers, but the AFI did not necessarily get credit for this. ${ }^{6}$ He recalled that the whole issue of peer assessment was problematic because it was difficult to find people to do assessments for the fund as so many were intending to apply for money for their own projects, or they knew the applicants personally and may not have been able to be objective. 
Berryman concluded that the AFI was doing its absolute best to implement transparent, fair and equitable decision making, and he credits the fund with having given incentive to Australians to do work of all kinds, not necessarily as a stepping stone to feature production. His thesis includes examples of the range of people who benefitted from the fund. At the commercial end they were persons such as Peter Weir who eventually launched a career in Hollywood, and Chris Fitchett who made numerous features in Australia. Experimenting in the margins were those such as Jeni Thornley, who made a short feminist film in Maidens in 1978 (a work intended for herself rather than any broad audience), and Gary Patterson who made a feature released through the film cooperatives, but eventually came to work primarily in super 8 film-making (Berryman 2008).

\section{Film artisans}

[...] with the establishment of its Experimental Film and Television Fund, the Government forged an unlikely alliance with probably the most far-out wing of the arts. (n.a. 1970)

Sue Ford stated that when a grant was received, the money was not forthcoming to the film-maker, but instead they had to go to the AFI offices in Carlton and get a 'pink slip', which was a kind of purchase order that they used to buy stock or have it developed (2008). John Flaus felt that this was most likely to have been the system developed because Erwin Rado was a careful man who did not want to fall foul of the establishment 
(2008). Artists generally provide the greatest funding for their work themselves, but while a poet or visual artist of the 1970s might have been able to use a grant to eat or pay rent, it was much more difficult for a film-maker to do so because their grants were strictly allocated to production costs (and the grants were very small). However, once the grants were given, there was no interference in the productions: the film-makers were free to do whatever they wanted with their films (unlike funding programmes today).

It is clear that from the AFI administrators' point of view, the EFTF was not intended to be commercial. AFI Chairman, Professor A. K. Stout, reinforced this when he said that while some of the films chosen might embarrass the government, 'through their apparent seditiousness or pornography... there can be no political tests applied to art' (n.a. 1969). And, in fact, the first film of the EFTF was politically controversial, a documentary film about the Vietnam Moratorium, [...] Or forever hold your peace (Brennan et al. ${ }^{7}$ 1970). The film documented a march by 30,000 people to the Sydney Town Hall to demand the Australian Government withdraw its troops from Vietnam and was shot by nine cameras (White 1970). Berryman has written of this film that it was an often-cited example of film-makers 'biting the feeding hand' (1985), and indeed, others have noted that for the politicians, the EFTF films squirmed 'embarrassingly alive in their grasp' (Lawson 1972: 18).

Other films from the first round of EFTF funding to receive exhibition in 1971 included Michael Thornhill’s Machine Gun, Bruce Petty’s Australian History, Sandra and Yoram Gross’ To Nefertiti and Peter Weir’s Homesdale (Hall 1971). However, the emphasis on film as art, and on experimentation, was not popular with all. Seven Network's Bruce 
Gyngell chastized the industry at the Awards ceremony for not making material for a mass audience; he bemoaned the experimental abstractions and what he saw as an industry in a ‘semi moribund state’ (n.a. 1971).

\section{Growing an industry}

Many of those who received grants went on to be key players in the industry at home and globally. This list includes Peter Weir, Bruce Beresford, Geoff Burton, Tim Burstall, Phil Noyce, Jan Chapman, Paul Cox, Scott Hicks, Yoram Gross, Erika Addis, Ken Sallows and Glenys Rowe. Philip Noyce observed that the EFTF grants were successful for a range of well-known film-makers, the ranks of which he would later join himself:

Tim Burstall made Stork on an EFTF grant, then went on to make Alvin Purple, Peter Weir made Homesdale on a grant, and went on to make The Cars That Ate Paris and he’s just started The [sic] Picnic At Hanging Rock, Tom Cowan made Office Picnic on a grant and went on to make Promised Woman, Mike Thornhill made Machine Gun on a grant and went on to make Between Wars. (quoted in Berryman 1985: 97) ${ }^{8}$

There were also many other less well-known film-makers who were making interesting films around the margins, such as Nigel Buesst, Andrew Pike, Aggy Read, Albie Thoms, Peter Tammer, Dusan Marek and Sue Ford. The list of those funded by the EFTF is distinguished, but as Berryman has pointed out, these people had made films previously, and may have progressed to features without EFTF grants; therefore, this does not necessarily quantify the impact of the EFTF. Despite this, it is arguable that through this fund the AFI was a significant player and supported people who were to be leading figures of the revival. In addition, the EFTF played a role not just in engendering 
momentum for the revival, but in fostering an understanding that a mainstream industry is deeply dependent on a cultural seed bed; as Carole Sklan has observed, 'Interesting film work does not emerge from a cultural vacuum [...]. There is a creative interaction between the films and the vitality of the culture from which they emerge' (1996: 236).

\section{The role of the EFTF in shaping the AFI}

The administration of the EFTF caused the AFI to become what Berryman described as a miniscule, vertically integrated organization. Not only was the AFI funding production, it had the rights to distribute films made under the auspice of the fund, and it eventually took up exhibition in order to promote those films as well. So this activity is extremely important in terms of how the AFI developed, because it led to an expansion of AFI activities. In 1970, the Vincent Film Library (which later evolved into AFI Distribution) was established to market and rent out what were largely Australian short films including films made through the EFTF. It was established with a federal government grant of \$31,000 and was named after Senator Seddon Vincent, who loved the arts and produced the Vincent Report, recommending assistance for the industry (he supported and recommended the establishment of government film bodies, a film school and tax rebate) and according to Barry Jones, he was one of John Gorton's closest friends (2006: 191).

Distribution was an issue for the EFTF given that the original idea of the fund was not so much to reach audiences, but to develop talent (and many of the films were low in commercial appeal in the sense they were unlikely to gain wide audiences). It was a condition of EFTF funding that film-makers give the AFI their film for distribution 
through the Vincent Library - something that caused consternation with some filmmakers who had wanted to have their own distribution rights, and were arguably better placed to actively promote their own films. According to Richard Brennan, when Albie Thoms made Sunshine City (1973) with EFTF money, he refused to deliver it to the AFI as contracted. Apparently, Thoms objected to certain attitudes held by the AFI and gave this as his reason for not supplying the film to them. However, Brennan (then the director of the AFI) decided not to pursue this through legal channels. Thoms was, however, pursued through the press, where articles were headed with titles such as 'Why my eyes throbbed in painful protest' (White 1973).

\section{The films}

In 2009, scholar Dr Alex Gerbaz surveyed the documents for the EFTF, which had been recently cleared for access under the 30-year rule (applications, correspondence, scripts, etc.). His overview is interesting, particularly because it includes some of the assessors' comments: that 16-year-old school boy Alex Proyas was given \$350 in 1978 to make a short animated surrealist film and the assessors saw "“a promising animation talent” [but] were concerned that he was "not definite about a career in animation" because "it would help the industry” if he was' (Gerbaz 2009). Although film-maker John Dunkley-Smith is described as misunderstood, he was nevertheless funded. His project reveals some of the structuralist thinking around his practice:

The 'film' that interests me most in any consideration of 'cinema' is not the strip of acetate that is eventually pulled through the gate of the projector in order to [be] shown on the screen, but rather, the 'film' that is constructed by the viewer as he/she apprehends, orders, re-orders the constituent elements of the 
projection/presentation/performance situation [...]. The effort of the viewer to determine structures (to organise experience) actually serves to transform (or reconstruct) the film's structure. (Gerbaz 2009)

This excerpt makes it clear that this archive contains a wealth of material about practice in Australian film history, a time capsule where a period of Australian modernist film practice has been frozen.

\section{The end of an era: The AFC takes over the EFTF}

[...] the Australian Film Commission is empire building, stretching its tentacles to take an Australian cinema activity into its commercially oriented embrace, even as it strangles some of it [...]. (Bennett 1977)

The AFI's tenure over the EFTF ended in 1977, and as Colin Bennett's writing in the press indicates (and he was a governor of the AFI at the time), the AFI was not happy about losing it. Bennett argued that running the fund would cost more under the AFC. There were mutterings among film-makers as to whether the AFC would be able and willing to take the kind of risks that the AFI had been prepared to take (with total novices). Annette Blonski has observed, 'if you look at the history, it didn’t take those risks'; she says that the EFTF was not given enough funding and 'became moribund' (2008). It is arguable that this was related to the AFC's approach to cultural policy; as scholar Mark Ryan has observed, cultural policy became narrower when the AFC 
replaced the AFDC, emphasizing cultural films and shutting out certain types of filmmaking, for example, genres such as horror (2009: 5).

By 1978 the EFTF ceased when it was amalgamated with other funds into a 'Creative Development Fund'. The other funds had been aimed at more experienced film-makers, and those whose output was more commercial in aiming for the largest possible audiences, and which were much more focused on narrative fiction and documentary: the Film Production Fund and the Script Development Fund.

The EFTF fulfilled an important role in germinating talent at a grass roots level, something that is still imperative but arguably given little priority today. As Gerbaz has observed:

Screen Australia, the recently formed federal development and film funding organisation, seems to have lost some of the spirit of experimentation that drove the industry in the 1970s. Federal support for experimental - and short filmmaking has been phased out almost entirely, with attention now focused on animation and feature films. Screen Australia has also indicated that it will give the green light exclusively to projects developed by what it calls 'established producers'. But if short filmmaking is to be ignored, and if only established producers can get their films made, where does this leave talented and innovative filmmakers with something new to say? In the 1970s, many such filmmakers got their start with the EFTF, and would have a significant influence on the burgeoning feature-film industry. (2009) 


\section{Conclusion}

Whether feeding the industry or supporting some alternative to the industry, the Experimental Fund was at the same time engaged in helping to shape Australian film culture. (Berryman 1985: 186)

In describing this period of Australian film history, George Miller has said that the industry at the time consisted of 'passionate amateurs'. He pointed out that there was an interaction between arts disciplines that fed off each other in the 1970s. Recalling the 1973 AFI Awards at the Kew Civic Centre, what struck him was that 'We were all a bunch of really passionate amateurs driven by our love of the cinema. That was the thing that for me really characterised the Australian film industry at the time’ (Miller 2008).

The example of the EFTF illustrates how a vibrant screen culture is the seedbed for a vivacious industry, and that the AFI was a significant player in nurturing talent, and making a noteworthy contribution to the renaissance of the industry in the 1970s. While we acknowledge that other organizations that have been briefly touched on in this article also played a role (and there is not room to expand on these here), it is the argument of this article that the AFI played a significant role through the EFTF, and that this is often not acknowledged in histories of the Australian film revival. As Dermody and Jacka have written (1988: 171), ${ }^{9}$ the AFI was successful in their tenure over the EFTF, supporting films that did not have an eye to commercial success, but rather were film-makers trying out ideas. From this perspective the EFTF (and the AFI) was performing a culturally and aesthetically important role in developing the expertise of film-makers and supporting the creation of interesting and challenging work. Through the EFTF, the AFI was a 
significant player in the development of modernist film practice in Australia in the earlyand mid-1970s.

\section{Acknowledgements}

The authors thank the interviewees for this research; Alexander Gionfriddo and the AFI Research Collection at RMIT; and the AFI for their support. Some parts of this article were drawn from Shining a Light: 50 Years of the Australian Film Institute (French and Poole 2009).

\section{References}

ABS (1974), 'Official year book of Australia, no. 60’, http://books.google.com.au/books?id=OFD5eudElygC\&pg=PA1022\&dq=Australia, ++ Fil $\underline{\mathrm{m}+\text { and+Television+Board\&hl=en\&ei=IotlTdSKNISuvgPQrrWsBg\&sa=X\&oi=book res }}$ ult\&ct=result\&resnum=1\&ved=0CD0Q6AEwAA\#v=onepage\&q=Australia $\% 2 \mathrm{C} \% 20 \% 2$ 0Film\%20and\%20Television\%20Board\&f=false. Accessed 22 February 2011.

Adams, P. (2008), Telephone Interview, Sydney, 14 July.

Bennett, A. (2008), Interview in person, Melbourne, 6 June.

Bennett, Colin (1977), 'Yet another domino totters', The Age, 10 September. Page number unavailable: article held in the AFI Research Collection clippings files.

Beresford, B. (1972), The Adventures of Barry McKenzie, Sydney: Longford Productions. 
Berryman, K. (1985), Allowing Young Filmmakers to Spread Their Wings: The

Educational Role of the Experimental Film and Television Fund, Massachusets: La Trobe University.

(2006), 'Putting 1975 in context', Metro: Film Television, Radio and New Media Magazine no. 150, pp. 178-79.

__ (2008), Video Interview, Melbourne, 27 August.

Blonski, A. (2008), Video Interview, Malvern, 26 August.

Brennan, Richard et Douglas White, Malcolm Smith, Arch Nicholson, Chris McCulloch, Brian Hannant, Kit Guyatt, Ian Dunlop, Frances Beaton. (1970), [...] Or forever Hold Your Peace, Sydney: Sydney Filmmakers Co-operative.

(2008), Video Interview, South Melbourne, 5 August.

Burstall, T. (1971), Stork, Melbourne: Bilcock \& Copping Film Productions and Tim Burstall \& Associates. (1973), Alvin Purple, Melbourne: Bi-Jay \& Hexagon Productions.

Cantrill, A. (1973), Skin of Your Eye, Melbourne: Arthur and Corrine Cantrill. 
Cowan, T. (1972), The Office Picnic, Sydney: Tom Cowan Productions.

__ (1975), Promised Woman, Sydney: BC Productions.

de Bruyn, D. (1977), Feyers, Melbourne: Dirk de Bruyn.

Dermody, S. and Jacka, E. (1987), The Screening of Australia: Anatomy of a Film Industry, vol. 1, Sydney: Currency Press.

(1988), The Screening of Australia: Anatomy of a Film Industry, vol. 2, Sydney: Currency Press.

Ellis, Bob (1972), 'Experimentalists 2', Lumiere, November, 18: p. 19.

Finney, A. (2007), 'Interview’, http://www.aftrsmedia.com/CSB/wpcontent/uploads/finney/finney.mp3. Accessed 25 October 2010.

Flaus, J. (2008), Video Interview, Melbourne, 1 May.

__ (2010), Guest Lecture, RMIT Cinema Studies course: ‘Australian Film’, 9 September.

Ford, S. (2008), Audio Interview, South Melbourne, 29 April. 
French, Lisa and Poole, Mark (2009), Shining a Light: 50 Years of the Australian Film Institute. Melbourne: ATOM.

Gardner, H., la Croix, H., Tansey R. G. and Kirkpatrick, D. (1991), Gardner's Art Through the Ages, 9th ed., San Diego: Harcourt Brace Jovanovich.

Gerbaz, A. (2008), 'Innovations in Australian cinema: An historical outline of experimental film', Journal of the National Film and Sound Archive, Australia, 1:3, 1, pp. 1-12, http://www.nfsa.gov.au/site_media/uploads/file/2010/09/09/NFSAJournal-Vol3No1-08.pdf. Accessed 23 February 2011.

_ (2009), 'The legacy of the experimental film and television fund, 1970-1978', National Archives of Australia, 13 October, http://www.naa.gov.au/whatson/audio/gerbaz-eftf.aspx. Accessed 23 February 2011.

Gibson, S. and Lambert, S. (1977), Ailsa: A Woman Sculptor, Sydney: Feminist Film Workers.

Gill, A. (1971), ‘A film land trigger-man’, Advertiser, 19 June, page number unavailable: article held in the AFI Research Collection clippings files.

Gross, S. and Y. (1971), To Nefertiti, Sydney: Yoram Gross Films Pty Ltd.

Hall, S. (1971), ‘The underground filmmakers crop up’, The Bulletin, 19 June, p. 35. 
Jones, B. (2006), A Thinking Reed, Crows Nest, NSW: Allen \& Unwin.

(2008), Video Interview, Melbourne, 1 May.

Lawson, Sylvia ([1965] 1985), 'Not for the likes of us’, in A. Moran and T. O’Regan (eds), An Australian Film Reader, Sydney: Currency Press, pp. 150-57.

_ (1972), 'Experimentalist 1', Lumiere, November, p. 18.

Miller, G. (2008), Telephone Interview, Sydney, 17 September.

Mudie, P. (1997), Ubu Films: Sydney Underground Movies, 1965-1970, Sydney: UNSW Press.

n.a..(no author attributed). (1969), ‘Gorton, not Goering’, Bulletin, 3 December, page number unavailable: article held in the AFI Research Collection clippings files.

_ (1970), 'Has Australia the cultural depth to support a film industry?', The Age, 25 September, page number unavailable: article held in the AFI Research Collection clippings files.

_ _ (1971), 'Film trade losing purpose’, Sydney Morning Herald, 4 December, page number unavailable: article held in the AFI Research Collection clippings files. 
Petty, B. (1971), Australian History, Sydney: Bruce Petty.

Petzke, I. (2004), Backroads to Hollywood: Phillip Noyce, Sydney: Pan Macmillan Australia.

Reade, E. (1981), History and Heartburn: The Saga of Australian Film, 1896-1978, Rutherford, NJ: Fairleigh Dickinson University Press.

Ryan, M. D. (2009), 'Whither culture? Australian horror films and the limitations of cultural policy’, Media International Australia Incorporating Culture and Policy, no. 133, pp. 43-55.

Sklan, C. (1996), 'Peripheral vision: Regionalism, nationalism, internationalism’, in Albert Moran (ed.), Film Policy: International, National and Regional Perspectives, London: Routledge, pp.234-248.

Stratton, D. (1980), The Last New Wave; The Australian Film Revival, London and Sydney: Angus \& Robertson.

Thoms, A. (1973), Sunshine City, Sydney: Sydney Filmmakers Co-operative. (1978), Polemics for a New Cinema, Sydney: Wild and Wooley.

Thornhill, M. (1971), The Machine Gun, Sydney: T \& M Productions. 
(1974), Between Wars. Sydney: Edgecliff Films/McElroy \& McElroy.

Thornley, J. (1978), Maidens, Sydney: Sydney Filmmakers Co-operative.

Weir, P. (1971), Homesdale, Sydney, Pan Films/Royce Smeal Film Productions

_ (1974), The Cars That Ate Paris, New South Wales: AFDC, Pan Films/Royce Smeal Film Productions.

(1975), Picnic at Hanging Rock, Victoria: AFC, McElroy \& McElroy and Picnic Productions.

White, M. (1970), ‘Gorton’s gift boomerangs with a kick’, Daily Mirror, 15 September, page number unavailable: article held in the AFI Research Collection clippings files.

__ (1973), 'Why my eyes throbbed in painful protest', TV Mirror, 30 March, p. 1.

Zuvela, D. (2003), 'The Ubu movement. An interview with Albie Thoms', Senses of Cinema, no. 27, http://www.sensesofcinema.com/2003/27/albie_thoms/. Accessed 24 February 2011.

\section{Suggested citation}

TBA 


\section{Contributors details:}

Lisa French is associate professor in Cinema Studies, Media and Communication at RMIT. She is the co-author of the books Shining a Light: 50 Years of the Australian Film Institute (2009) and Womenvision: Women and the Moving Image in Australia (2003), and producer of Birth of a Film Festival (2003), a film about the first Melbourne International Film Festival. She is currently undertaking a major research project examining women's participation in Australia’s film, television, video and multimedia industries.

Mark Poole is a Melbourne-based writer/director and Chair of the Australian Writers' Guild, Victoria. He has written more than twenty hours of television drama, including the AFI award-winning telefeature A Single Life; he co-produced and directed the documentary Fearless, screened on the ABC (2010); and he is a contributor to the online journal Screen Hub and other publications such as The Age, Metro and Storyline. He is also an occasional lecturer in RMIT's School of Media and Communication, and the coauthor of Shining a Light: 50 Years of the Australian Film Institute (2009).

\section{Contact:}

Bld 9, Level 4, RMIT University, 124 La Trobe St, Melbourne, Vic. 3000, Australia.

E-mail: $\underline{\text { lisa.french@rmit.edu.au }}$

E-mail: mark.poole@rmit.edu.au

Notes 


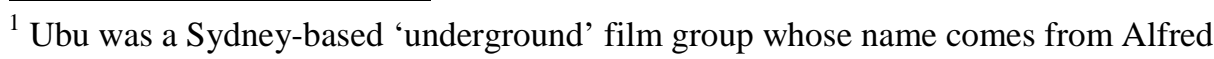
Jarry's nineteenth-century absurdist play Ubu Roi (Mudie 1997: 18).

${ }^{2}$ While the AFI ran the EFTF, there were four different authorities who provided the funding over their tenure; from 1970 The Australian Council for the Arts; 1971-1972 the Interim Council for a National Film and Television Training School; 1973-1976 the Film and Television Board of the Australian Council for the Arts; and 1976-1977 the Creative Development Branch of the Australian Film Commission, who took over the EFTF in $1977-1978$.

${ }^{3}$ Stratton notes that in Sydney the lobby centred around an industry group called the AFC that aimed to bring all the crafts and unions together with one voice - very like the proposed Screen Council (which the industry has been trying to establish at the time of writing this book and which problematically aims at the one voice).

${ }^{4}$ Berryman documents the time the AFI ran the fund and notes that only 521 projects were completed to release print (1985: 67); 45.9\% were drama, 24\% documentary; $23.8 \%$ experimental and 6. 3\% animation (1985: 69); they were shot on various gauges: 8mm, 16mm, 35mm and video (1985: 71); and the majority of recipients were from NSW and Victoria (80\%) (1985: 75).

${ }^{5}$ This is an indicator that the term 'experimental' is not necessarily adequately descriptive. See Thoms (1978: 7583) for a more detailed discussion of the term.

${ }^{6}$ It is the view of the authors of this article that the AFI has rarely been given credit for what it achieved: Berryman and Dermody and Jacka are amongst the few scholars who 
have. The legacy of the EFTF does speak for itself, and clearly did make an important contribution to Australian culture.

${ }^{7}$ Various people are listed in the National Film and Sound Archive database as directors of this film: Richard Brennan, Douglas White, Malcolm Smith, Arch Nicholson, Chris McCulloch, Brian Hannant, Kit Guyatt, Ian Dunlop, Frances Beaton. Brennan was only able to get \$2000 from the EFTF for the film, so to make up the extra $\$ 1200$, he got 120 people to give him $\$ 10$ each, and their names appear at the end of the film, mixed with those who worked on it.

${ }^{8}$ The quoted original source is the AFI Board minutes from 20 November 1976.

${ }^{9}$ They were specifically discussing the period 1970-1973. 